\title{
ANALISA DAN PERANCANGAN SISTEM REKRUTMEN DOSEN BERBASIS WEB
}

\section{Budi Zaenal Abidin dan Zainil Abidin}

STIMIK LIKMI, Institut Manajemen Wiyata Indonesia

Email: bj.zaenalabidin@gmail.com dan zainilabidin@imwi.ac.id

\section{Abstract}

Lecturers are an important part of Higher Education. The key to success of graduates is quality of lecturers. At present, in the recruitment manual process of lecturers take quite a lot of time. Other than that, the archiving process is also poorly organized and in large numbers takes up large space. To make the process more effective but still efficient can be done by applying current technological advances by using internet media. Therefore E-Recruitment will be the best solution. Review the problem, Writer will make Analysis of recruitment system design base of web to help recruitment proccess uses SDLC method and Unified Modeling Language (UML) instrument.

Keywords: E-Recruitment, SDLC and UML

\section{Abstrak}

Dosen merupakan bagian penting di Perguruan Tinggi. Kunci kesuksesan dari lulusan adalah Dosen yang berkualitas. Saat ini, dalam proses manual rekrutmen dosen cukup memakan waktu yang banyak. Selain itu proses pengarsipannya pun kurang tertata dan dengan jumlah yang banyak sehingga memakan ruang yang besar. Untuk membuat proses lebih efektif namun tetap efisien bisa dilakukan dengan menerapkan kemajuan teknologi saat ini yaitu dengan menggunakan media internet. Maka dari itu E-Recruitment akan menjadi solusi terbaik. Melihat permasalahan tersebut penulis akan membuat Analisa perancangan sistem rekrutmen berbasis web untuk membantu proses rekrutmen dengan metode SDLC dengan menggunakan alat Unified Modeling Language (UML).

Kata kunci: E-Recruitment; SDLC; UML

\section{Pendahuluan}

Informasi menjadi sebuah kebutuhan yang pokok, agar dapat terus memperbaharui biasanya mencari dan mendapatkannya melalui media cetak, elektronik dan internet. Seperti halnya makhluk hidup yang membutuhkan makan, maka informasi juga sudah menjadi kewajiban untuk segera dipenuhi, jika tidak terpenuhi maka bisa berpengaruh buruk bagi penggunanya khususnya dunia pendidikan (Saputra, Ishak, \& Setiaji, 2019). Pendidikan Tinggi merupakan tahap akhir dalam pendidikan formal dengan berbagai jenis jenjang pendidikan tinggi. Sedangkan menurut Umar 
Tirtarahardja dalam (Eryanto \& Swaramarinda, 2013), jenjang pendidikan adalah suatu tahap dalam pendidikan berkelanjutan yang ditetapkan berdasarkan tingkat perkembangan peserta didik serta keluasan ke dalam bahan pengajaran Perguruan Tinggi merupakan penyelenggara program pendidikan dalam bentuk yang bermacammacam. Keberadaan Pendidikan Tinggi bagi masyarakat sudah menjadi kebutuhan utama sebagai bagian investasi Sumber Daya Manusia (SDM) (Ismail \& Helmawati, 2018). Berbeda dengan investasi lainnya, dalam pendidikan melibatkan berbagai pihak tidak hanya dari penyedia jasa yang menyiapkan pendidik, sarana $\&$ prasarana, tetapi juga yang melakukan investasi tersebut yaitu peserta didiknya. Selain itu ada juga keterkaitan aturan-aturan yang diberlakukan oleh pemerintah, serta dunia usaha dan industri yang turut serta berkontribusi sebagai pengguna lulusan nantinya. Maka dari itu investasi SDM dibidang pendidikan membutuhkan proses yang cukup panjang. Dan dosen adalah bagian dari investasi SDM bagi Perguruan Tinggi sehingga Dosen yang berkualitas akan didapat melalui proses yang cukup Panjang, yang dimulai dari saat rekrutmen dosen. Kualitas dan komitmen tenaga edukatif (dosen) yang ditunjang oleh sarana dan prasarana yang memadai serta lingkungan yang kondusif, akan memberikan kepuasan tersendiri bagi dosen dan ini merupakan kunci utama keberhasilan sebuah lembaga pendidikan tinggi (Ainayyah, 2019).

Institut Manajemen Wiyata Indonesia merupakan perguruan tinggi swasta yang lokasi dalam penelitian ini. Sebagai perguruan tinggi baru dengan usia yang masih muda, menjadi institusi yang masih semangat dalam mengembangkan sebuah sistem. Dalam Standar operasional (SOP) rekrutmen, dosen adalah standar yang memiliki keterkaitan dengan peraturan-peraturan pemerintah yang berlaku. Dalam pelaksanaannya proses rekrutmen ini terbagi kedalam beberapa tahapan yaitu:1. Pengajuan dari Program Studi, 2. Pembukaan Lowongan dan 3. Proses Rekrutmen.

\section{Metode Penelitian}

Dalam hal ini peneliti menggunakan metode SDLC dengan menggunakan Unified Modeling Language (UML) sebagai alat desain.

\section{SDLC}

Planning, analysis, design, dan implementation merupakan empat fase dasar yang digunakan dalam mebangun sebuah sisten informasi dengan SDLC, seperti gambar berikut ini:

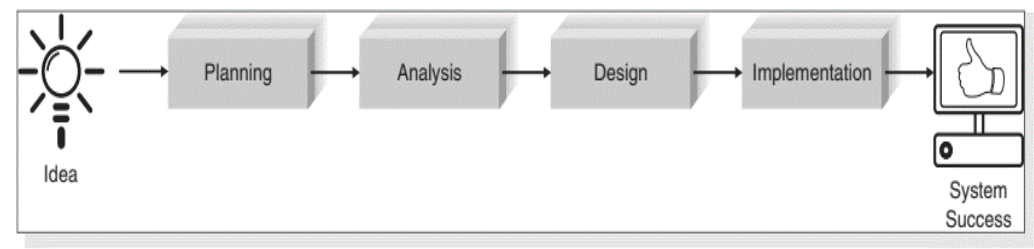

a. Planning atau fase perencanaan adalah proses awal untuk memahami mengapa sistem informasi ini harus dibangun dan menentukan bagaimana tim proyek akan membangunnya (Syamsiyah \& Sesunan, 2018). 
b. Analysis atau fase analisis adalah fase menjawab pertanyaan tentang siapa yang akan menggunakan sistem, apa yang akan dilakukan sistem, dan di mana serta kapan akan digunakan.

c. Design atau fase rancangan memutuskan bagaimana sistem akan beroperasi dalam hal perangkat keras, perangkat lunak, dan infrastruktur jaringan yang akan ada; antarmuka pengguna, formulir, dan laporan yang akan digunakan; dan program khusus, basis data, dan file yang akan dibutuhkan.UML

d. Implementation atau fase Penerapan yang merukan fase terakhir dalam SDLC di mana sistem tersebut benar-benar dibangun.

\section{UML}

Unified Modelling Language (UML) diterima sebagai bahasa standar untuk pengembangan objek pada tahun 1997. Unified Modelling Language (UML) adalah sebuah "bahasa" yg telah menjadi standar dalam industri untuk visualisasi, merancang dan mendokumentasikan sistem piranti lunak. UML menawarkan sebuah standar untuk merancang model sebuah sistem (Sri \& Romi, 2012). UML bukan sebuah metode tapi Bahasa yang saat ini banyak digunakan. Selain itu, di bidang analisis dan desain sistem saat ini telah menggabungkan konsep dan teknik berorientasi objek, di mana sistem dilihat sebagai kumpulan objek independen yang mencakup data dan proses. Objek dapat dibangun sebagai bagian individu dan kemudian disatukan untuk membentuk sistem, yang mengarah pada komponen proyek yang modular dan dapat digunakan kembali.

UML terdiri atas pengelompokkan diagram-diagram sistem menurut aspek atau sudut pandang tertentu. Dan diagram adalah yang menggambarkan permasalahan ataupun solusi atas permasalahan. Ada 9 diagram UML, yaitu (Fauzan, 2018):

a. Use-case, diagram yang menggambarkan aktifitas apa saja yang dilakukan oleh suatu sistem dari sudut pandang pengamatan luar.

b. Class, diagram yang memberikan pandangan secara luas dari suatu sistem dengan menunjukan kelas-kelasnya serta hubungan mereka

c. Object dan Package, diagram untuk mengatur pengorganisasian Class yang kompleks, dan dapat dilakukan dengan melakukan pengelompokan Class berupa package.

d. State, diagram yang menunjukan akan kemungkinan dari keadaan obyek serta proses yang menyebabkan perubahan pada keadaannya.

e. Sequence, merupakan diagram Interaction yang menjelaskan tentang bagaimana suatu operasi itu dilakukan;

f. Collaboration, merupakan diagram Interaction lebih fokus pada kegiatan obyek dari waktu pesan itu dikirimkan serta kapan pelaksanaannya

g. Activity, merupakan diagram yang umum digunakan dalam flowchart namun fokus terhadap aktifitas-aktifitas yang terjadi terkait dalam suatu proses tunggal.

h. Component, merupakan diagram yang menggambarkan fisik sebenarnya dari Class. 
i. Deployment diagram, merupakan diagram yang menerangkan konfigurasi fisik software dan hardware.

\section{Userinterface}

Userinterface atau antarmuka pengguna adalah bagian dari sistem yang digunakan pengguna untuk berinteraksi. Ini termasuk tampilan layar yang menyediakan navigasi melalui sistem, layar dan formulir yang menangkap data, dan laporan yang dihasilkan sistem (Muslihudin, 2016). Desain antarmuka pengguna merupakan cara bagaimana menentukan interaksi pengguna dengan sistem serta sifat input dan output yang diterima dan diproduksi oleh sistem. Antarmuka pengguna mencakup tiga bagian mendasar. Yang pertama adalah mekanisme navigasi, yaitu cara pengguna memberikan instruksi kepada sistem serta memberi tahu apa yang harus dilakukan (contohnys., Tombol, menu). Yang kedua adalah mekanisme input, yaitu bagaimana sistem dapat menangkap informasi (mis., Formulir untuk menambah pelanggan baru). Yang terakhir adalah mekanisme output, yaitu cara sistem menyediakan informasi kepada pengguna atau sistem lain seperti Laporan, halaman Web.

\section{Hasil dan Pembahasan}

\section{Activity Diagram}

Pembukaan Penerimaan Dosen

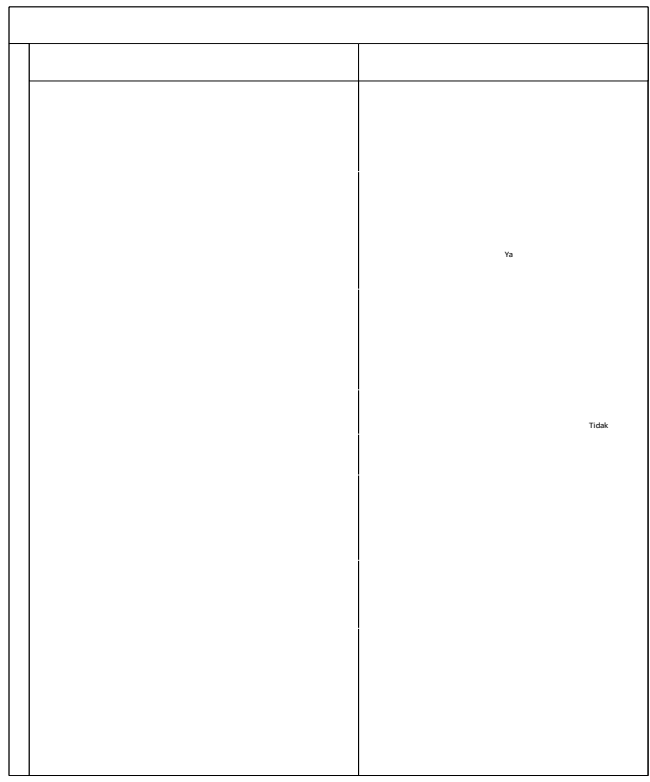

Pembukaan Penerimaan Dosen
Pelamaran Dosen

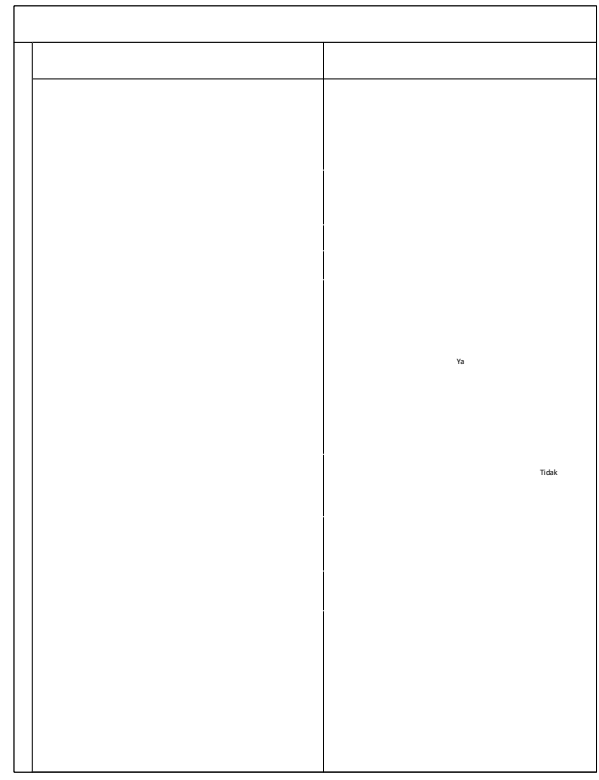

Pelamaran Dosen 

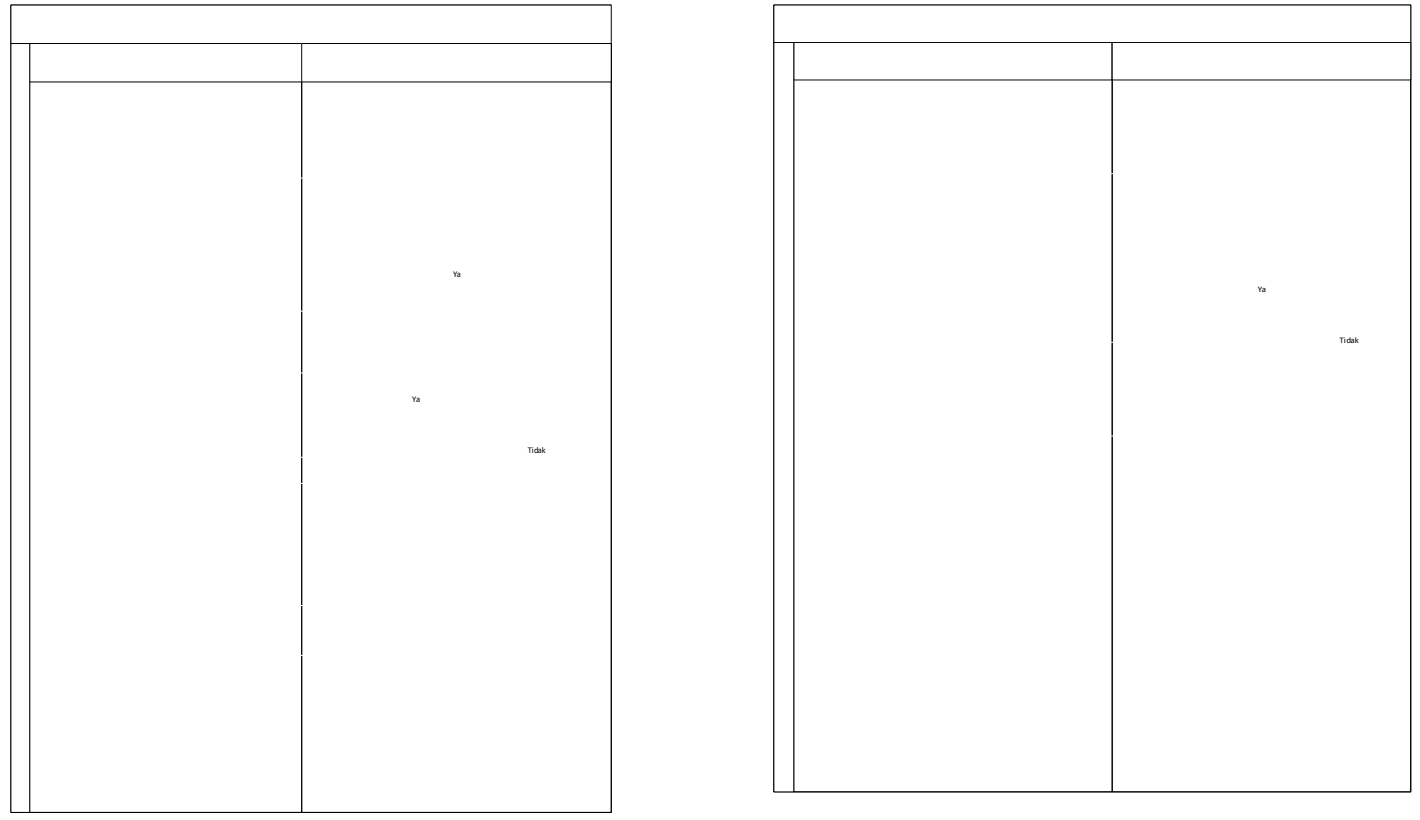

\section{Class Diagram}

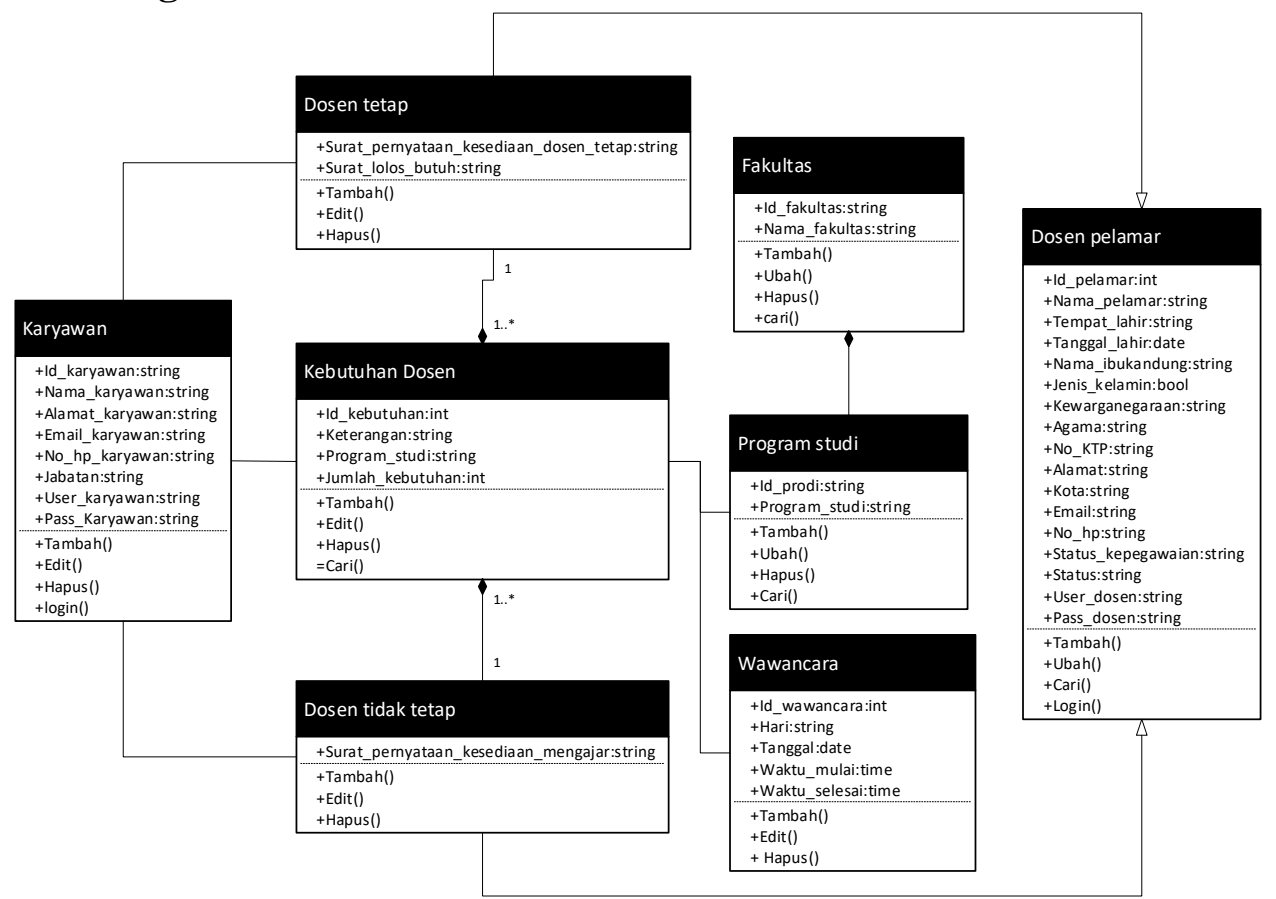




\section{Sequence Diagram}

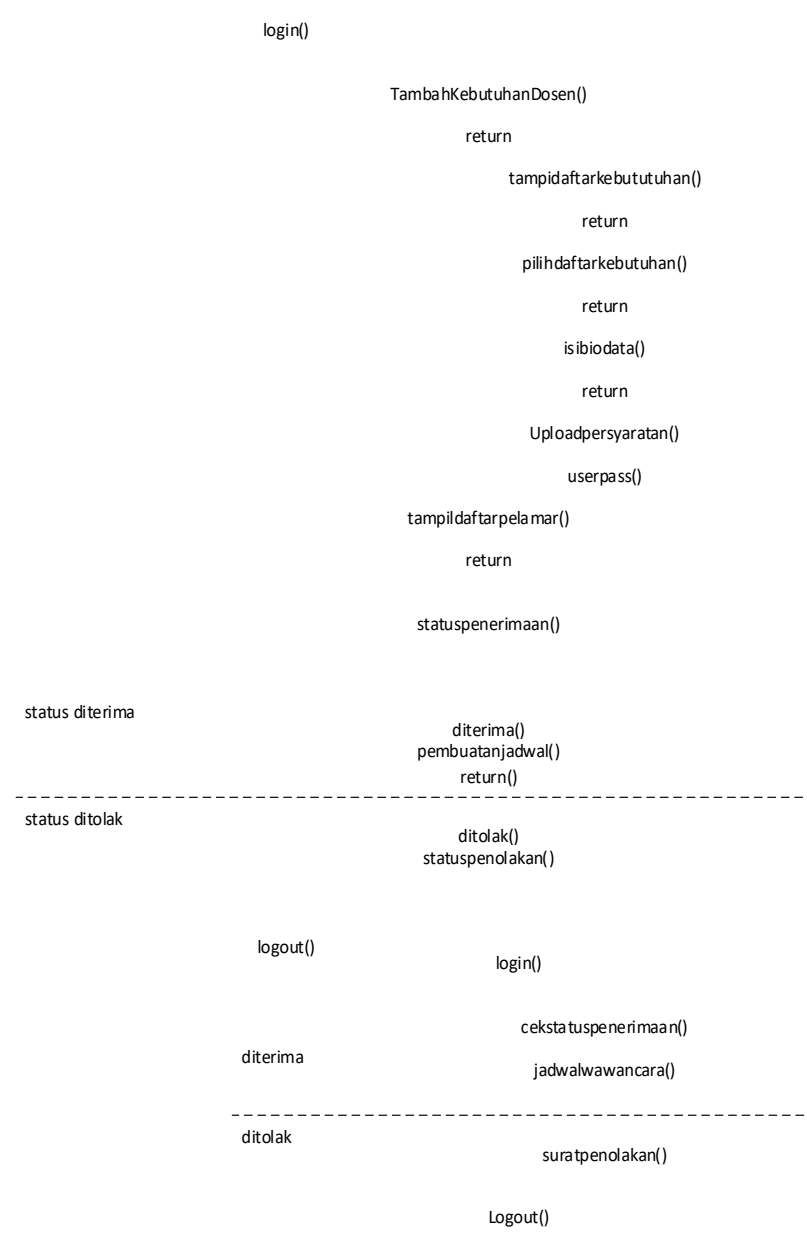

4. Usulan User Interface (Ui)

a. Halaman Log In

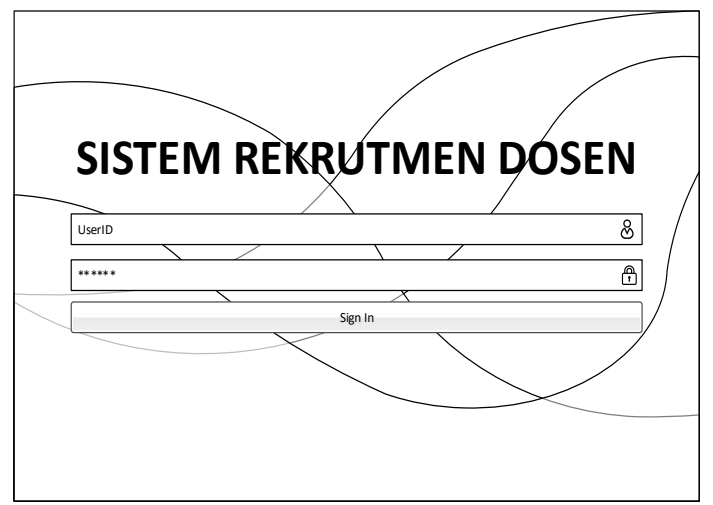


b. Halaman Manajemen Kebutuhan Dosen untuk user SDM

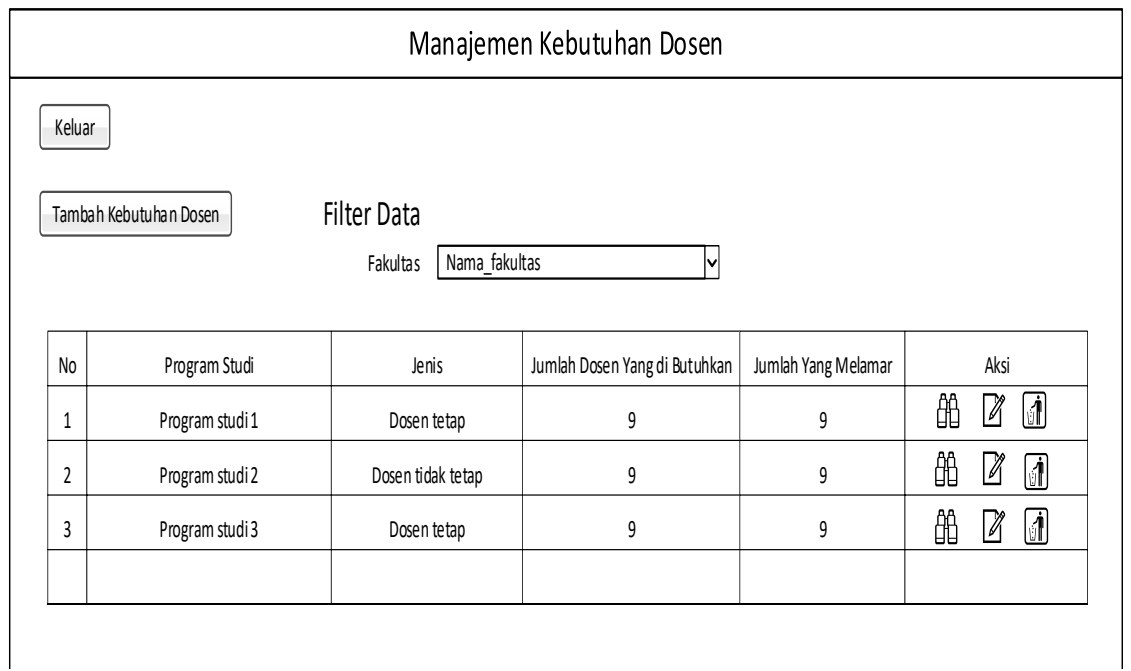

c. Halaman Tambah Kebutuhan Dosen untul User SDM

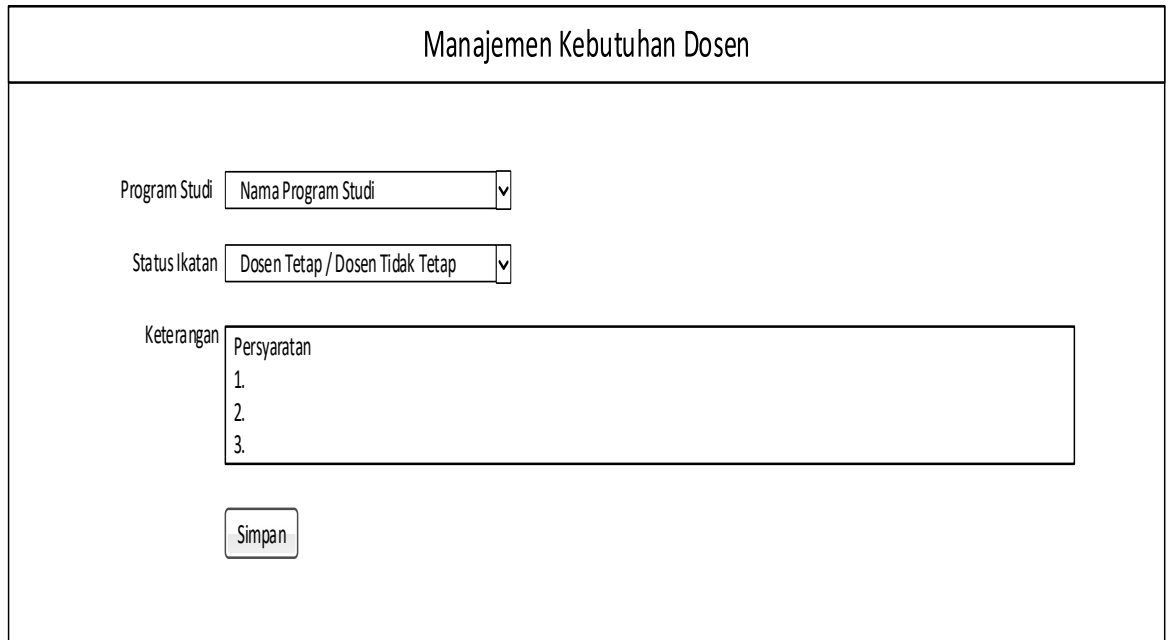

d. Detil Daftar Kebutuhan Dosen yang diakses oleh User

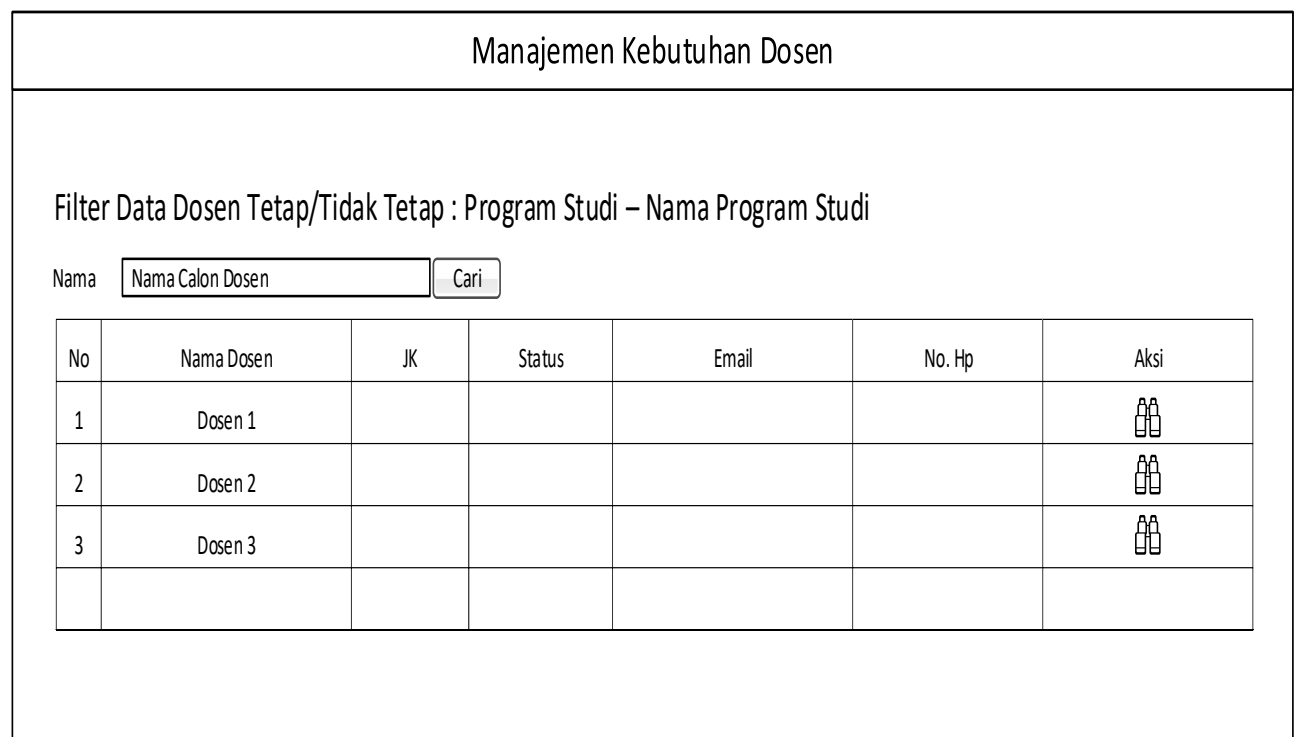


e. Profil Pengajuan Dosen yang diakses oleh User

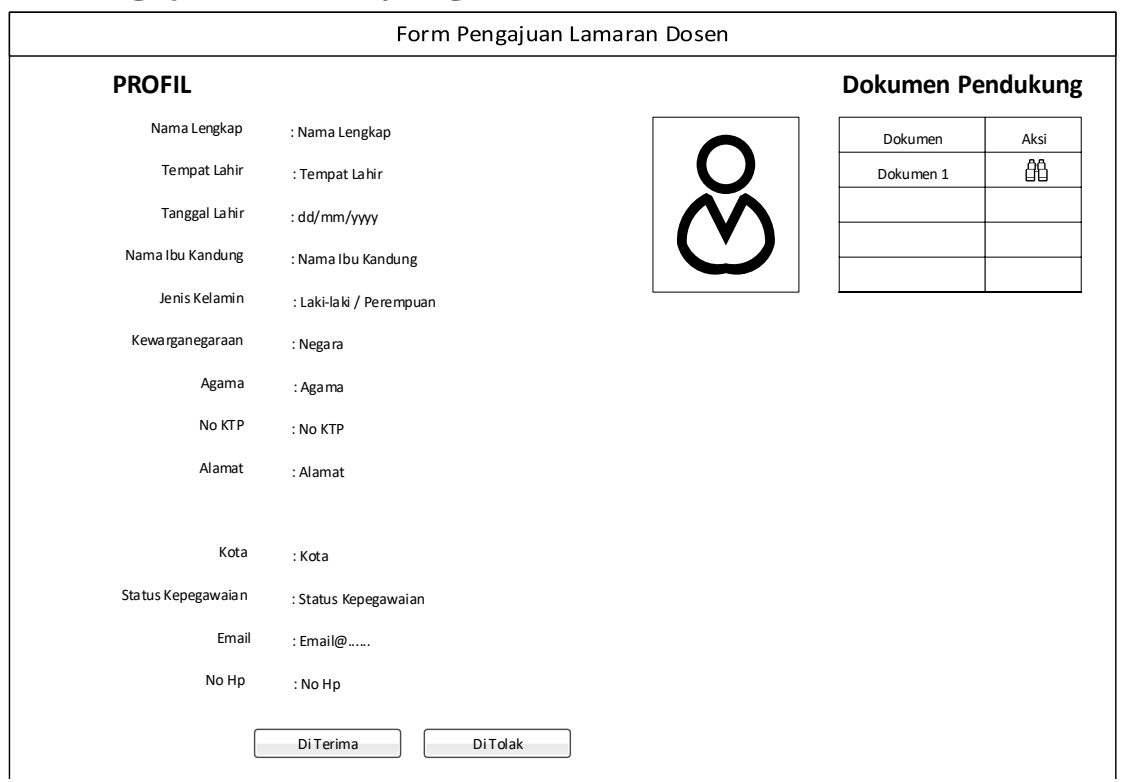

\section{f. Halaman Manajemen Wawancara oleh User SDM}

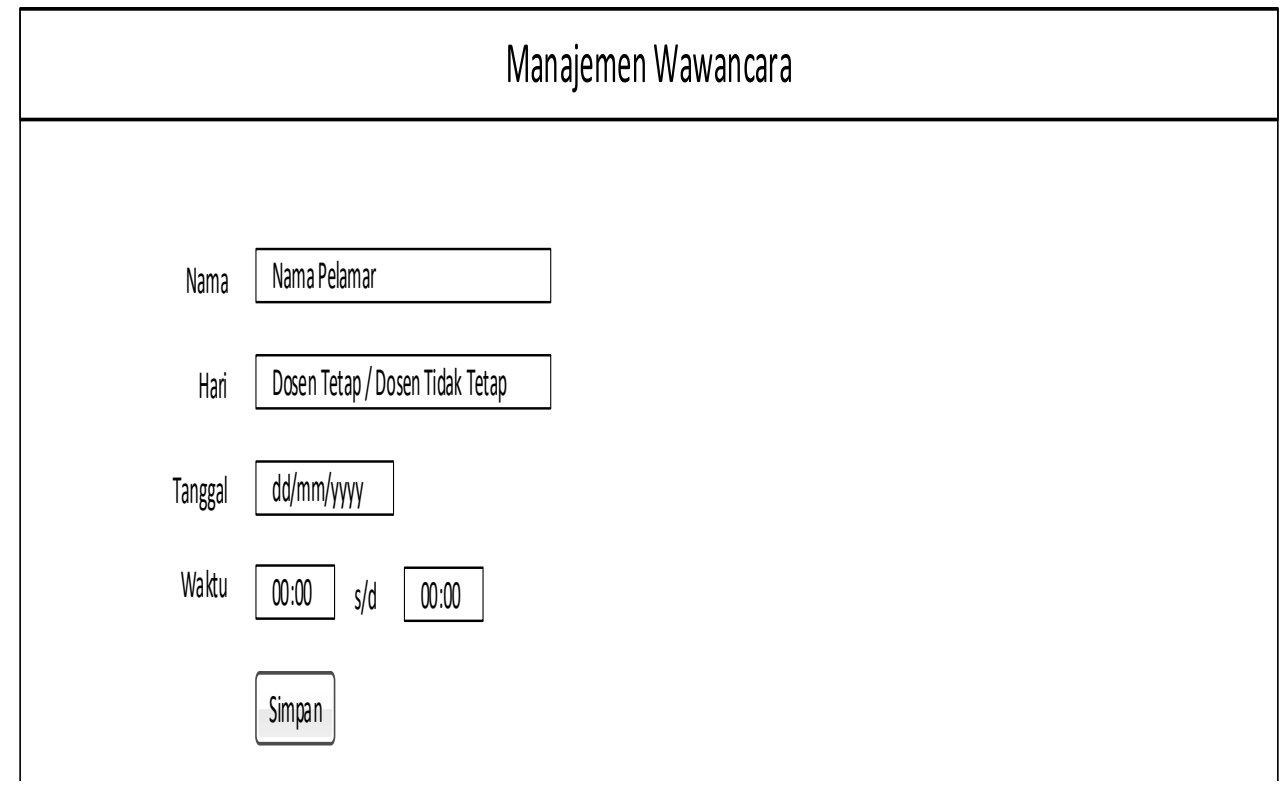


g. Halaman Daftar Kebutuhan Dosen yang di akses oleh calon dosen

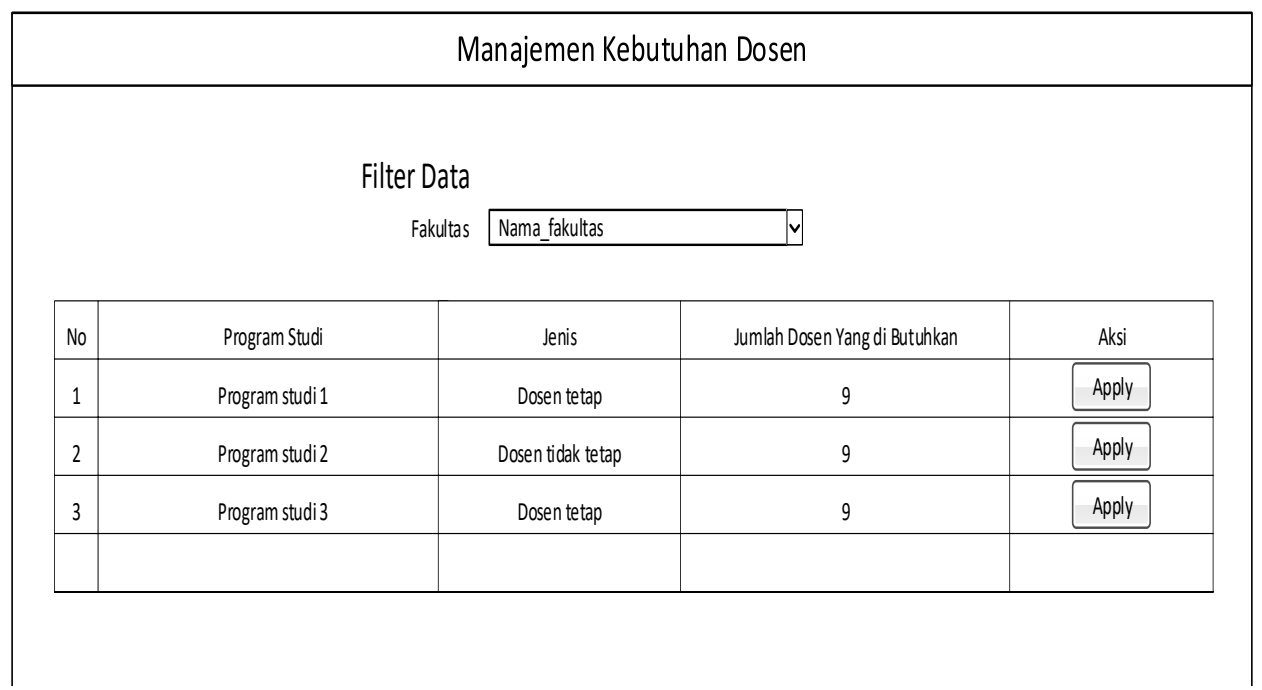

h. Halaman Pengajuan Lamaran Dosen

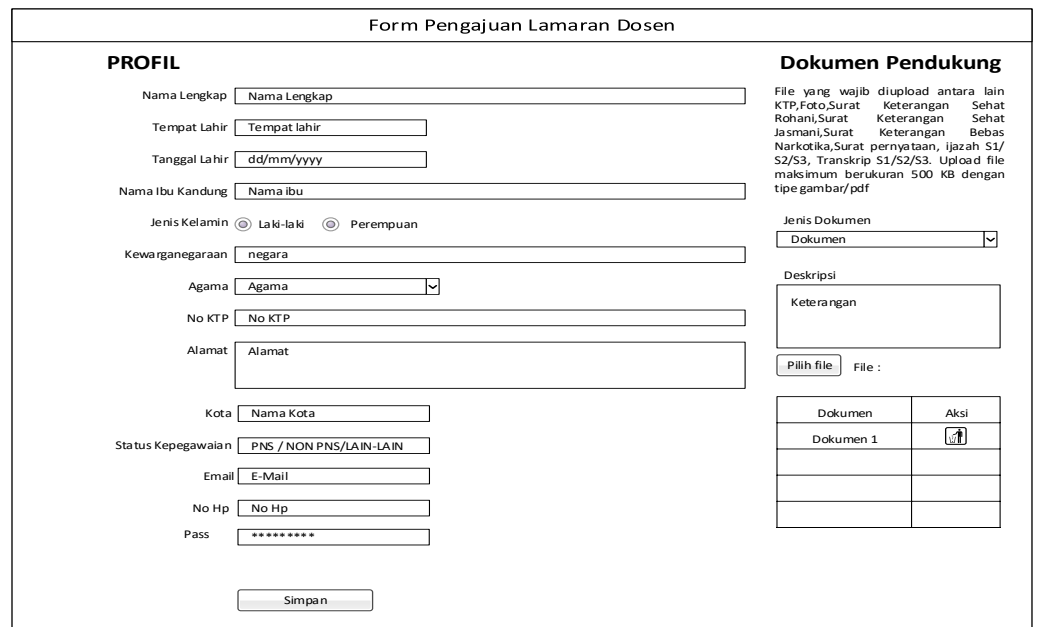

i. Halaman Status Pengajuan

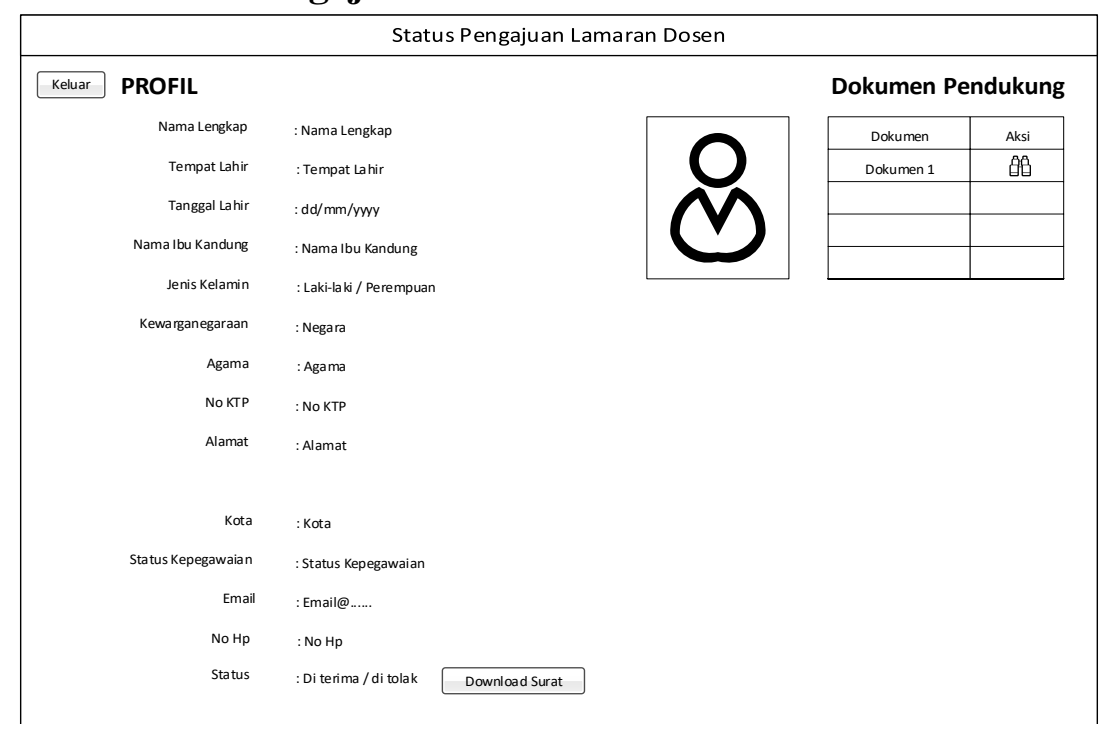




\section{j. Surat Pemberitahuan Jadwal Wawancara}

\begin{tabular}{|c|c|}
\hline \multicolumn{2}{|c|}{ Kepada Yth. } \\
\hline \multicolumn{2}{|c|}{ Nama Lengkap Dosen } \\
\hline \multicolumn{2}{|l|}{ Di } \\
\hline \multicolumn{2}{|l|}{ Tempat } \\
\hline \multicolumn{2}{|c|}{ Dengan Hormat, } \\
\hline \multicolumn{2}{|c|}{$\begin{array}{l}\text { Dengan ini kami beritahukan, bahwa kami telah melihat surat lamaran anda yang menyatakan bersedia } \\
\text { untuk menjadi do sentetap/dosentidak tetap di Institut Manajemen Wfiyata Indonesia. Maka dari itukami } \\
\text { mengundang Bapak/ibu untuk dapat hadir dalam proses wawancara yang akan dilaksanakan pada : }\end{array}$} \\
\hline & : Hari \\
\hline Tanggal & : dd mmmm yyyy \\
\hline \multirow[t]{2}{*}{ Tempat } & : Kampus Institut Manajemen Wiyata Indonesia \\
\hline & Jalan Gudang No, 7-9 Kota Sukabumi. \\
\hline \multicolumn{2}{|c|}{ Demikian surat ini kami sampaikan, semoga saudara dapat bergabung dengan perguruan tinggi kami. } \\
\hline \multicolumn{2}{|c|}{ Sukabumi, dd mmmm yyyy } \\
\hline \multicolumn{2}{|c|}{ Hormat Kami } \\
\hline \multicolumn{2}{|c|}{ Kepala Bagian Sumber Daya Manusia } \\
\hline \multicolumn{2}{|l|}{ TD } \\
\hline \multicolumn{2}{|c|}{ 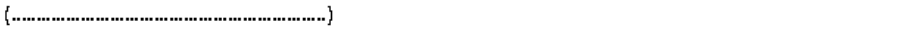 } \\
\hline
\end{tabular}

\section{k. Surat Penolakan Lamaran}

Kepada Yth.

Nama Lengkap Dosen

$\mathrm{Di}$

Tempat

Dengan Hormat,

Dengan ini kami beritahukan, bahwa kami telah melihat surat lamaran anda yang menyatakan bersedia untuk menjadi dosen tetap/dosen tidak tetap di Institut Manajemen Wiyata Indonesia.

Namun dengan berat hati kami sampaikan, bahwa kami harus menolak lamaran sadara, karena ada beberapa hal kualifikasi yang belum terpenuhi.

Demikian surat ini kami sampaikan, semoga suatu saat nanti saudara dapat bergabung dengan perguruan tinggi kami.

Sukabumi, dd mmmm yyyy

Hormat Kami

Kepala Bagian Sumber Daya Manusia

TTD

\section{Arsitek Sistem}

Arsitektur menentukan kebutuhan pengguna dan kemudian merancang dan membangun sistem untuk memenuhi kebutuhan tersebut seefektif mungkin dalam kendala ekonomi dan teknologi. Untuk meminimalis sistem yang akan 
digunakan maka perlu adanya kolaborasi arsitektur client side dan server side. Dengan skema sebagai berikut:

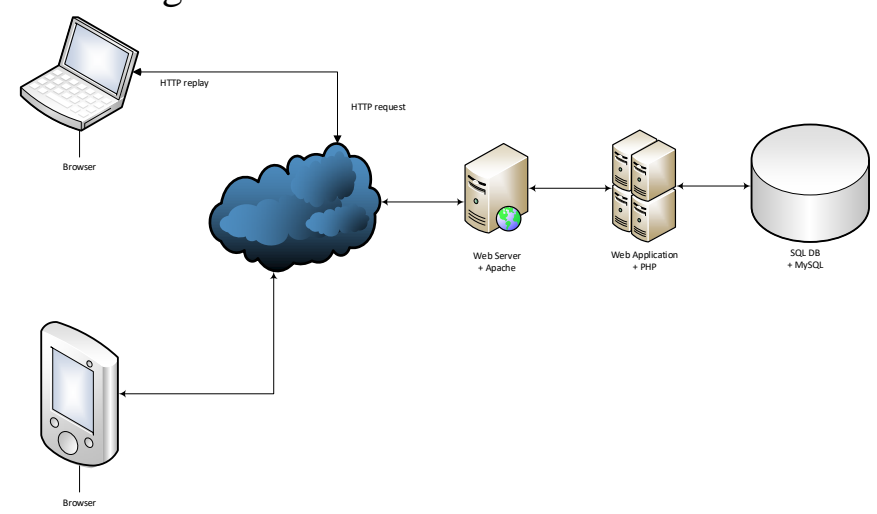

Aplikasi dibangun dengan berbasis web yang didukung dengan PHP sebagai web application, MySQL sebagai DBMS dan apache sebagai web server. Sehingga aplikasi bisa di akses oleh client dimana saja melalui media internet dengan laptop/pc, atau smartphone yang dimilikinya selama memiliki browser.

\section{Kesimpulan}

Perancangan sistem ini dapat membantu perguruan tinggi dalam memenuhi kebutuhan dosen sesuai kompetensi, dan keahlian yang sesuai. Perancangan sistem ini dapat membantu para calon dosen sebagai pelamar dengan melamar pekerjaan yang tersedia dengan cepat dan tepat. 


\section{BIBLIOGRAFI}

Ainayyah, Dita Nitami. (2019). Meningkatkan SDM dari Perguruan Tinggi. Retrieved from Kompasiana website: https://www.kompasiana.com/dita70138/5dc98a58d541df296a3e9533/meningkatk an-sumber-daya-manusia-sdm-dari-perguruan-tinggi?page=all

Eryanto, Henry, \& Swaramarinda, Darma Rika. (2013). Pengaruh Modal Budaya, Tingkat Pendidikan Orang Tua dan Tingkat Pendapatan Orang Tua Terhadap Prestasi Akademik Pada Mahasiswa Fakultas Ekonomi Universitas Negeri Jakarta. Jurnal Pendidikan Ekonomi Dan Bisnis (JPEB), 1(1), 39-61.

Fauzan, Ibnu Fajar. (2018). Pemanfaatan Social Network Analysis Untuk Sistem Jejaring Sosial Jurusan Teknik Komputer. Universitas Komputer Indonesia.

Ismail, Rudihartono, \& Helmawati, M. Pd I. (2018). Meningkatkan Sdm Berkualitas Melalui Pendidikan.

Muslihudin, Muhamad. (2016). Analisis Dan Perancangan Sistem Informasi Menggunakan Model Terstruktur Dan UML. Penerbit Andi.

Saputra, Dedi, Ishak, Riswandi, \& Setiaji, Setiaji. (2019). Perancangan Website ECommerce Sebagai Media Penjualan Miniatur Bus. Syntax Literate; Jurnal Ilmiah Indonesia, 4(12), 87-103.

Sri, Dharwiyanti, \& Romi, S. (2012). Pengantar Unified Modeling Language (UML). Ilmu Komputer. Com, Tanggal Akses, 6.

Syamsiyah, Nur, \& Sesunan, Mira Febriana. (2018). Penerapan Metode System Life Cycle Development Dan Project Management Body of Knowledge Pada Pengembangan Sistem Informasi. Ikra-Ith Informatika: Jurnal Komputer Dan Informatika, 2(2), 1-9. 